\title{
ILMU PENDIDIKAN PSIKOLOGI TERHADAP KUALITAS SUMBER DAYA MANUSIA
}

\author{
Resty Nurqomah \\ 2010128220014@mhs.ulm.ac.id \\ Program Studi Pendidikan IPS Fakultas Keguruan dan Ilmu Pendidikan \\ Universitas Lambung Mangkurat
}

\begin{abstract}
Abstrak
Pembelajaran pendidikan merupakan sesuatu hal yang dimilki masyarakat, di mana setiap indidvidu memiliki peluang dalam mempunyai pendidikan, dengan tidak terbatas karena ketidaksanggupan pada finansial, kemampuan fisik, maupun karena sosial-budaya. Pemerintahan ataupun penyelenggaraan pada pembelajaran haruslah mengusahakan mendapat akomodir kesuluruhan warga negara pada penduduk usia sekolah yang ada pada melibatkan fungsi pendidikan itu sendiri. Pembelajaran memiliki peranan sangat penting serta ada pada tahapan pertama melaksanakan manajemen pembelajaran dengan jadi selaku petunjuk untuk melaksanakan, mengendalikan, serta mengawasi dalam menyelenggarakan pembelajaran. adanya butuh terhadap pembelajaran, mengakibatkan terjadi komples warga negara, yaitu permasalahan peningkatan masyarakat, dibutuhkan ketenagaan kerja, permasalahan pada lingkungan, serta terbatasnya sumber daya alam. Meningkatnya kwalitas sumber daya pada manusia ialah secara merangkai usaha menjadikan individu keseluruhan serta penduduk indonesia semuanya, yakni membangun manusia, secara insan ataupun selaku sumber dalam pengembangan. Pengembangan individu selaku insan serta sumber dalam pengembangan merupakan penekanan hak, martabat, kewajiban serta hakikat manusia.
\end{abstract}

Kata Kunci: Pendidikan, Ilmu Psikologi, Kualitas, Sumber Daya Manusia

\section{Pendahuluan}

Pendidikan pembelajaran di wilayah Indonesia terjadi krisis besar, dikarenakan pengembangan pada butuhnya pembelajaran tidak memenuhi dari adanya sumber yang ada. 
Beberapa tahun yang lalu (Coombs, 1968) serta (Manap, 1999, 2008) memberitahu supaya pembelajaran dapat dibuat rencana dengan seksama. Yakni dilihat dari terbatasnya juga arahan pada yang menyelenggarakan pembelajaran dengan benar sesuai dengan yang dibutuhkan pada pengembangan penduduk. Evaluasi pembelajaran, diberi tugas pada buku mata pelajaran, memperbaiki, serta pengayaan dilaksanakan melalui tugas itu, kalau hasil peserta didik tidak memenuhinya ketetapan yang ditetapkan (Aunurrahman, 2009; Jumriani, 2021; Wahidmurni, 2017). Dalam memperbaiki masalah pendidikan pembelajaran digunakan dengan komprehensif. (Banghart \& Trull, 1973: 120) memberitahu tentang suatu hal yang perlu dilihat pada saat membuat rencana dalam pendidikan, yakni (1) identifikasi dari banyaknya peraturan pada fungsi pembelajaran itu, (2) evaluasi serta pertimbangkan dari banyaknya cara metode dalam pembelajaran serta apakah berkaitan pada permasalahan pembelajaran, (3) cermati permasalahan krisis yang dirasa diperlukan adanya perkembangan, diteliti serta perhatian,

(4) evalusi unggul dan lemahnya fungsi pembelajaran yang tersedia, dan (5) lakukan suatu hal yang dikaji pada fungsi pembelajaran serta komponennya. Melakukan rencana akan mempunyai fungsi dalam mengarahkan pada pelaksanaan aktifitas secara sistematis, tembus pandang, serta komprehensif. Indidvidu pada pembelajaran, arahan, serta manfaat dari banyaknya sumber daya yang dapat berguna pada pelaksanaan mencapai yang dituju serta bisa menjadikan selaku benda mengendalikan mengenai mencapai sesuatu hal yang dituju itu. (Engkoswara, 1987, ISPI, 1995, Manap, 1999, 2008) Pada pendidikan pembelajaran adanya rencana, melaksanakan, mengendalikan, serta mengawasi tentang (ketersediaan kelengkapan, uang, kurikulum serta sumber daya manusia) agar dapat menuju pada hal yang dituju yakni pendidikan, baik efisien maupun efektif. Peningkatan kualitas manusia dengan memahami pada manusai itu sendiri adalah suatu hal penting. Sebab menggambarkan hasil terkandung pada diri individu, secara logika, estetika, ataupun etika. Perkembangan individu selaku insan yang tidak punya batasan pada penduduk umur sebagaimana. Tapi melangsungkan pada keseluruhan kehidupan individu, seperti kelompok individu yang melakukan pembangunan pada konteks pembelajaran pendidikan.

\section{Pendidikan}

Pendidikan di dapat dari keluarga ditanamkannya hasil kebudayaan, berupa peraturan, cara memandang, bersikap dalam hidup, serta terampil pada kehidupan bermasyarakat (Abbas, 2002, 2018a, 2018b; Abbas, 2018; Hardian, 2006). Pendidikan adalah tercapainya komunikasi individu dalam perkebangan menjadi manusia yang utuh, serta pendidikan pembelajaran ialah 
pelaksanaan secara menerus serta akan selalu tumbuh. Pendidikan merupakan pelaksanaan pada berubahnya perilaku serta suatu cara kelompok mengusahakan pendewasaan individu lewat pengupayaan ajaran juga latihan. Pembelajaran formal pada kelompok merupakan perkembangan dalam mampu terhadap keinginan dilakukan kelompok tersebut. Jadi pendidikan ialah pelaksanaan pendewasaan yang terarah lebih positif, sehingga mampu melakukan perkembangan sesuai keinginan pada kelompok tersebut. Potensi diri adalah hal utama yang jadi perhatian seorang, sebab dia memperhatikan kepada cara kerja internasional yang masuk. Walaupun tinggi pendidikan seorang, jika tidak ahli dalam melaksanakan hal yang perlu diketahui, akibatnya berhasilnya itu akan jauh pada dirinya sendiri. Ilmu pengetahuan serta keahlian terampil berhubungan pada pekerjaan jasa berupa karier, di mana pendidikan ini memiliki komponen, yakni:

1. Sesuai rencana serta menyadari melakukannya,

2. Terwujud lingkungan belajar serta pelaksanaan pembelajaran, supaya siswa aktif dalam menumbuhkan potensi yang dimilikinya,

3. Mempunyai power religius, mengendalikan diri, sifat pribadi, cerdas, akhlak baik, juga terampil terhadap warga serta bangsa negara.

Pendidikan memiliki beberapa faktor yang berpengaruh, yaitu:

1) Ideologi, seluruh umat manusia lahir di kehidupan memiliki hak selaras, terutama dalam mendapat pendidikan juga meningkatkan ilmu pengetahuan.

2) Ekonomi-sosial, tingginya sosial-ekonomi kemungkinan seorang dapat tercapai kualitas pendidikan tinggi.

3) Budaya-sosial, umumnya orang tua tidak sadar dengan penting dalam mendapat pendidikan, terutama formal pada anaknya.

4) Meningkatnya ilmu pengetahuan dan teknologi, pertumbuhan ini mengharuskan selalu dapar berbaur pada hal baru, seperti ilmu pengetahuan juga keahlian terampil supaya tidak akan terkalahkan bersaing pada negara maju.

5) Psikologi, konsep pendidikan adalah benda perkembangan pribadi manusia supaya mempunyai nilai tersendiri.

\section{Ilmu Psikologi}

Salah satu aliran ilmu psikologi merupakan psikologi behavioristik yang dipergunakan dalam kajian pembelajaran serta belum banyak menekankan pada konteks konstitusi. Sikap ataupun behavior ialah permasalahan pada psikologi pembelajaran. Sikap siswa supaya bisa 
memahami ataupun menguasai ialah upaya diri siswa pada penafsiran, kalau siswa ialah proses dewasa. Melaksanakan pembelajaran bisa memiliki nilai perubahan bersikap (Abbas, 2017; Putro, 2020, Subiyakto \& Mutiani, 2020). Ada pula pendidik berupaya supaya bisa menguasai ataupun dipahami oleh siswa yang belum berusia. Sikap saat sebelum memahami ataupun menguasai dibanding dengan sikap setelah memahami ataupun menguasai, ialah objek pengamatan dari kelompok behavioris. Sikap bisa berbentuk perilaku, perkataan, serta aksi seorang sehingga sikap ini ialah bagian dari psikologi dinamis. Psikologi dinamis merupakan psikologi spesial menggarap permasalahan ketenagaan batin, didorong, serta motif yang pengaruhi sikap seorang maupun kelompok. Salah satu gunanya psikologi pembelajaran merupakan awal sikap individu. Pembelajaran berusaha meningkatkan sikap kehidupan yang positif. Hasil positif dengan moral maupun tingkah laku diwariskan dari leluhur, dengan mudah hilang sebab globalisasi (Putra, 2019).

\section{Perencanaan Ilmu Pendidikan Psikologi}

Perencanaan pendidikan social studies ialah usaha sadar melaksanakan belajarpembelajaran di ruang kelas pada konsep susunan jelas hingga tercapainya nilai memuaskan (Mutiani, 2020; Sapriya, 2017; Syaharuddin \& Mutiani, 2020). Merencanakan manajemen pembelajaran pada pendidikan psikologi dapat terarah untuk menolong dalam (1) pemenuhan kebutuhan ketenagakerjaan, (2) memperluas peluang pembelajaran psikologi, (3) meningkatkan kualitas pembelajaran psikologi, juga (4) meningkatkan efektif serta efisien dalam menyelenggarakan pembelajaran psikologi. Merencanakan pembelajaran menyesuaikan kesanggupan, dukungan, keterampilan, kesanggupan bermasyarakat, emosi, keinginan cara belajar, melatar belakangi kebudayaan, serta ruang peserta didik (Abdullah, 2012; Abbas, 2015).

Memenuhi kebutuhan ketenagakerjaan terlatih serta memiliki kualitas, bertempat pada hal yang utama, sebab didukungnya ketenagakerjaan terlatih, sehingga perkembangan dalam berbagai hal sulit terlaksana serta meningkatnya pengangguran. Keperluan pada pendidikan akan selalu meningkat, sehingga diperlukan meratanya peluang untuk mendapat pendidikan tersebut dengan bebas sifatnya merakyat serta politis. Selain hal itu meningkatnya efektif serta efisien dalam menyelenggarakan pembelajaran ialah suatu hal yang harus dipenuhi untuk mewujudkan kebutuhan ketenagakerjaan serta meluasnya peluang dalam mendapat pendidikan. Tujuannya mempunyai sifat ekternal dengan memiliki latar belakang klasik mengenai pada merencanakan pendidikan, yakni:

1. Social demand approach,

2. Manpower planning approach, serta 


\section{Rate of return approach.}

Awal hal positif juga moral terlaksana dengan di awasi serta di bimbing (Mutiani, 2009; Subiyakto, 2020; Subiyakto \& Mutiani, 2020). Penekanan menuju pendidikan mempunyai misi bebas, yaitu bebas dalam masyarakat dengan terhindar dari sifat bodoh dan miskin. Contohnya kebutuhan pada pendidikan terpenuhi, implementasi pada peraturan diwajibkan belajar, serta bebas dana terhadap penduduk yang terbatas ekonomi. Dalam pendekatan misi bebas ini, adalah cara merencanakan dengan mengakomodisi supaya seluruh masyarakat mendapat pendidikan terpenuhi sesuai dana yang normal.

\section{Sumber Daya Manusia Pada Kepribadian Psikologi}

Personality ataupun karakter "persona", “topeng”, ialah perlengkapan buat menyembunyikan bukti diri. Untuk bangsa Romawi persona "gimana seorang nampak pada orang lain", jadi bukan diri sesungguhnya. Terjemahan dari person, ataupun "persona" "manusia selaku seorangan", "diri manusia ataupun diri orang sendiri”. Dikatakan kalau individu merupakan "saya yang sejati" serta "penampakan saya" dalam wujud sikap tertentu. Timbulnya gagasan universal kalau karakter merupakan kesan yang diberikan seorang kepada orang lain yang didapat dari apa dipikir, dialami, serta diperbuat yang terungkap lewat sikap. Karakter itu bisa berubah serta antar bermacam komponen karakter tersebut semacam kerutinan, perilaku, nilai, kepercayaan, emosi, perasaan, serta motif yang mempunyai ikatan erat.

Ikatan tersebut terorganisasi sedemikian rupa secara bersama-sama pengaruhi pola sikap dalam membiasakan diri. Melakukan kegiatan pembelajaran sampai siswa memiliki pengalaman, sebab belajar secara efisiensi... (Abbas, 2021; Mutiani, 2019, 2021). Fieldman menggambarkan selaku sikap yang normal dari individu yang ditunjukkan pada perilaku serta berkelanjutan pengalaman masa kemudian. Dan Chambers menggambarkan karakter ialah perihal aneh yang tidak dapat di perhitungkan bila berdialog tentang diri sendiri hendak nampak berbeda dengan tiap orang. Pergantian dalam karakter tidak terjalin secara otomatis, namun hasil pematangan, pengalaman, penekanan dari area sosial-budaya, serta akibat dari orang.

1. Pengalaman dini, berartinya pengalaman dini pada masa anak- anak dalam pertumbuhan karakter (Sigmund Freud).

2. Pengaruh kebudayaan, menerima kebudayaan anak hadapi tekanan buat meningkatkan pola karakter cocok dengan standar yang di tetapkan budaya.

3. Keadaan raga, mempengaruhi langsung serta tidak langsung terhadap karakter seorang. Keadaan badan memastikan apa yang bisa dicoba serta apa yang tidak bisa dicoba seorang. 
Secara tidak langsung seorang hendak dirasakan mengenai badannya pula mempengaruhi dari perasaan orang lain pada badannya. Keadaan raga dipengaruhi karakter antara lain: letih, kendala raga, penyakit menahun, serta kendala kelenjar endokrin ke kelenjar tiroid (risau, marah, hiperaktif, penekanan mental, tidak selalu puas, curigaan, serta sebagainya).

4. Energi tarik, orang menilai dari lingkungan menarik umumnya mempunyai lebih banyak ciri karakter di idamkan daripada orang yang dinilai kurang menarik, serta untuk yang memiliki ciri menarik hendak menguatkan perilaku sosial yang menguntungkan.

5. Inteligensi, kepedulian yang lewat pada anak pandai bisa menjadikan dia sombong, serta anak yang kurang pandai merasa bodoh apabila bersebelahan dengan orang yang pandai.

6. Emosi, ledakan emosi tanpa sebab yang besar di nilai selaku orang yang tidak matang. Penekanan ekspresi emosional malah buat seorang sedih hati serta cenderung agresif, tidak ingin bekerja sama serta sibuk dengan dirinya sendiri.

7. Nama, meski cuma semata nama namun mempunyai pada mempengaruhi konsep diri, tetapi pengaruhnya cuma dirasa apabila anak sadar gimana nama berpengaruh pada kehidupanya.

8. Keberhasilan serta Kegagalan, keberhasilan serta kegagalan hendak mempengaruhi konsep diri, kegagalan bisa mengganggu konsep diri, sebaliknya keberhasilan mendukung konsep diri itu.

9. Penerima sosial, anak diterima pada suatu kelompok sosial bisa meningkatkan rasa yakin diri serta kepandaian yang dimiliki. Kebalikan anak tidak diterima dalam area sosial hendak membenci orang lain, cemberut, serta gampang tersinggung.

10. Efek keluarga, efek keluarga sangat berpengaruh pada karakter anak, dikarenakan paling banyak anak ialah bersama keluarga serta pada keluarga letak hal mengawali karakter.

11. Pergantian raga, pergantian karakter bisa diakibatkan sebab terdapatnya pergantian kematangan raga yang menuju kepada revisi karakter. Namun pergantian raga yang menuju pada klimakterium dengan meningkatnya umur selaku mengarah ke arah yang lebih kurang baik.

\section{Simpulan}

Pendidikan adalah tercapainya komunikasi individu dalam perkebangan menjadi manusia yang utuh, serta pendidikan pembelajaran ialah pelaksanaan secara menerus serta akan selalu tumbuh. Jadi pendidikan ialah pelaksanaan pendewasaan yang terarah lebih positif, sehingga mampu melakukan perkembangan sesuai keinginan pada kelompok tersebut. Ada pula pendidik berupaya supaya bisa menguasai ataupun dipahami oleh siswa yang belum berusia. 
Pembelajaran berupaya meningkatkan sikap kehidupan yang positif. Salah satunya merencanakan manajemen pembelajaran pada pendidikan psikologi dapat terarah untuk menolong dalam, serta meningkatkan kualitas pembelajaran psikologi. Merencanakan pembelajaran menyesuaikan kesanggupan, dukungan, keterampilan, kesanggupan bermasyarakat, emosi, keinginan cara belajar, melatar belakangi kebudayaan, serta ruang peserta didik (Abdullah, 2012; Abbas, 2015). Memenuhi kebutuhan ketenagakerjaan terlatih serta memiliki kualitas, bertempat pada hal yang utama, sebab didukungnya ketenagakerjaan terlatih, sehingga perkembangan dalam berbagai hal sulit terlaksana serta meningkatnya pengangguran. Selain hal itu meningkatnya efektif serta efisien dalam menyelenggarakan pembelajaran ialah suatu hal yang harus dipenuhi untuk mewujudkan kebutuhan ketenagakerjaan serta meluasnya peluang dalam mendapat pendidikan. Penekanan menuju pendidikan mempunyai misi bebas, yaitu bebas dalam masyarakat dengan terhindar dari sifat bodoh dan miskin. Contohnya kebutuhan pada pendidikan terpenuhi, implementasi pada peraturan diwajibkan belajar, serta bebas dana terhadap penduduk yang terbatas ekonomi. Timbulnya gagasan universal kalau karakter merupakan kesan yang diberikan seorang kepada orang lain yang didapat dari apa dipikir, dialami, serta diperbuat yang terungkap lewat sikap. Karakter itu bisa berubah serta antar bermacam komponen karakter tersebut semacam kerutinan, perilaku, nilai, kepercayaan, emosi, perasaan, serta motif yang mempunyai ikatan erat. Melakukan kegiatan pembelajaran sampai siswa memiliki pengalaman, sebab belajar secara efisiensi... (Abbas, 2021; Mutiani, 2019, 2021). Fieldman menggambarkan selaku sikap yang normal dari individu yang ditunjukkan pada perilaku serta berkelanjutan pengalaman masa kemudian. Seperti Keadaan raga, mempengaruhi langsung serta tidak langsung terhadap karakter seorang. Keadaan badan memastikan apa yang bisa dicoba serta apa yang tidak bisa dicoba seorang. Ataupun pergantian raga, pergantian karakter bisa diakibatkan sebab terdapatnya pergantian kematangan raga yang menuju kepada revisi karakter.

\section{Referensi}

Abbas, E. W. (2019). Building Nation Character Through Education: Proceeding International Seminar on Character Education.

Amelia, R., Putro, H. P. N., \& Permatasari, M. A. (2020). The Role of Caregivers as a Social Attitude Developer in The Children's Social Homes Budi Mulia Banjarbaru. The Kalimantan Social Studies Journal, 2(1), 56-61. 
Dewi, A. P., \& Rusdinal, R. (2020). PERKEMBANGAN KARIR GURU. JMKSP (Jurnal Manajemen, Kepemimpinan, dan Supervisi Pendidikan), 5(1), 8-13.

H Djaali, D. (2007). Psikologi pendidikan.

Ilmiyannor, M., \& Mi'rajiatinnor, D. (2021, February). Strengthening Environmental Care Attitudes Through Social Wisdom-Based Social Studies Learning. In The 2nd International Conference on Social Sciences Education (ICSSE 2020) (pp. 65-69). Atlantis Press.

Indriyani, I. E., Syaharuddin, S., \& Jumriani, J. (2021). Social Interaction Contents on Social Studies Learning to Improve Social Skills. The Innovation of Social Studies Journal, 2(2), 93102.

Pasaribu, L. (2019). PENGEMBANGAN KARIR GURU. MANAJER PENDIDIKAN, 13(3), 265-272.

Pendidikan, M. (2013). Peraturan Menteri Pendidikan dan Kebudayaan Republik Indonesia. Nomor, 66, 1-3.

Putra, M. A. H., Mutiani, M., Jumriani, J., Ramadhan, S., \& Rahmatina, R. (2020). Utilization Learning Management System (LMS) of Ruang Guru for Education Teachers in Banjarmasin. The Kalimantan Social Studies Journal, 2(1), 31-38.

Rahayu, R., Abbas, E. W., \& Jumriani, J. (2021). Social Studies Lesson Planning for Children with Intellectual Disabilities in the Pembina State Special School of South Kalimantan Province. The Kalimantan Social Studies Journal, 2(2), 160-169.

Rahmat, P. S. (2021). Psikologi pendidikan. Bumi Aksara.

Somantri, M. (2014). Perencanaan pendidikan.

Susanto, H. (2020). PEDAGOGI SEJARAH, NASIONALISME DAN KARAKTER BANGSA. Preprint: EdArxiv

Yusuf, K. M., Tarbawi, T., \& Tentang, P. P. A. Q. A. (2013). Pendidikan. Jakarta: Amzah. 